\title{
Роля на конексините за \\ слуховата загуба при човека
}

\author{
И. Станчева, О. Стоянов, Сп. Тодоров \\ Катедра по УНГ-болести, МУ - София \\ УМБАЛ „Царица Йоанна-ИСУЛ“ - София
}

\begin{abstract}
Резюме
Конексините са група структурни протеини. Те образуват при гръбначните животни трансмембранни канали, през които преминават йони и малки молекули (1). Експресират се в различни тъкани на организма и имат значение за важни физиологични процеси като деполяризацията на сърдечния мускул, слуховото възприятие, ембрионалното развитие и др. Връзката между конексините и вътрешното ухо е добре позната. Експресията на различни конексини във вътрешното ухо демонстрира тяхната важност за слуховото възприятие. Установени са над 100 мутации в гените, кодиращи конексините, свързани със слухова загуба. Най-засегнат е конексин 26. Мутациите в гена GJB2, кодиращ конексин 26, са отговорни за повече от $50 \%$ от генетичната несиндромна слухова загуба.
\end{abstract}

Ключови думи конексин (Сx), слухова загуба, gap јunction 


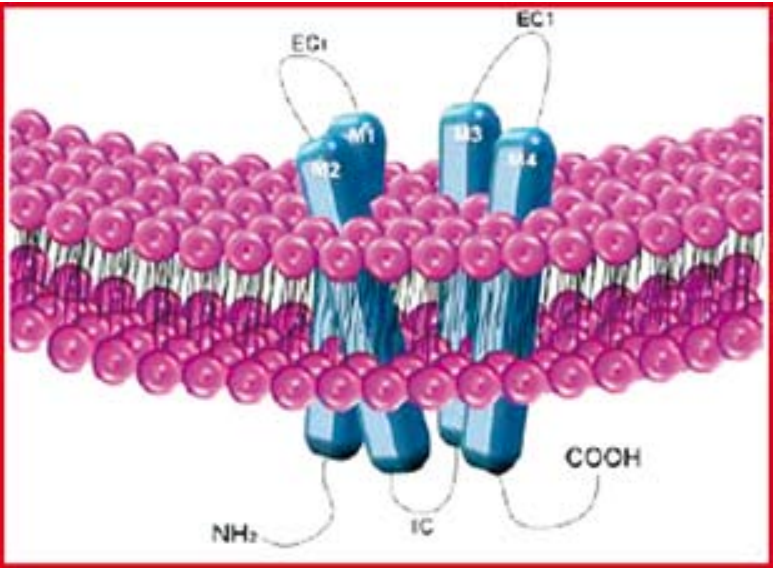

Фиг. 1. Структура на конексина

Конексините се събират в групи по шест, за да формират полуканал, наречен конексон, в цитоплазмените мембрани. При обединяването на два полуканала на съседни клетки се получава трансмембранен канал, наречен gap junction. Той осигурява транспорта на различни йони и малки молекули-сAMP, cGMP, ATP, аминокиселини, глутатион и др.

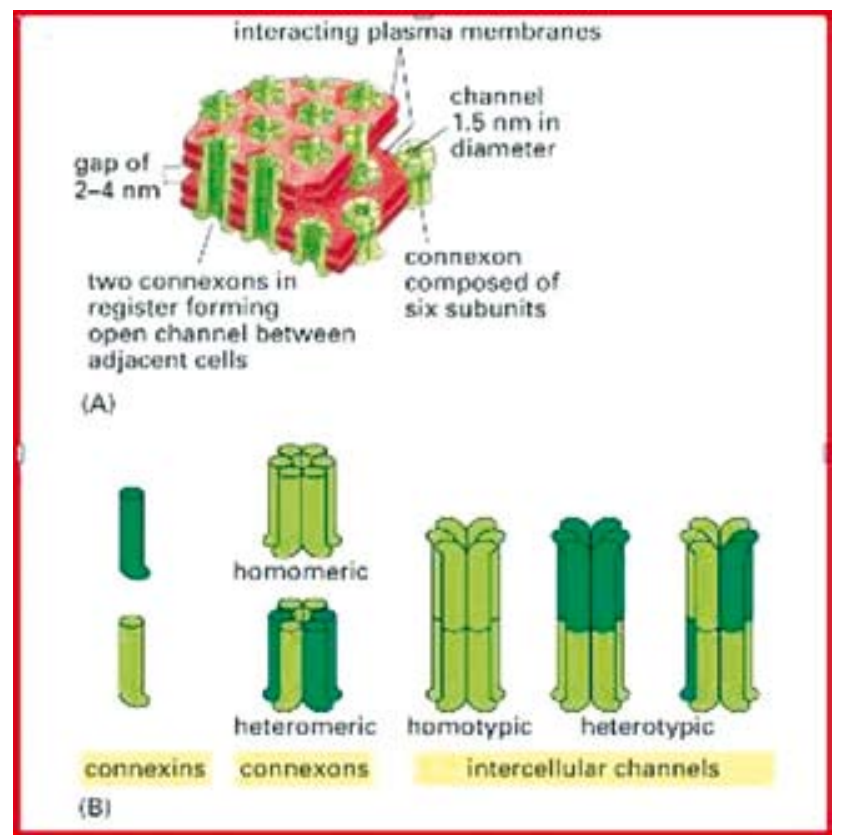

Фиг. 2. Структура на конексона и gap junction

Конексоните могат да бъдат хомомерни (шестте субединици са изградени от една изоформа) и хетеромерни (от различни изоформи). При човека са идентифицирани 21 конексина. Те са с молекулно тегло 26 и $60 \mathrm{kDa}$ и са със средна дължина 380 аминокиселини. Конексините имат сравнително кратьк полуживот. Те се синтезират в рибозомите, преминават в ендоплазмения

\section{МБ оториноларингология}

ретикулум и през апарата на Голджи. Готовите конексони се транспортират до цитоплазмените мембрани. Свързвайки се с конексон на съседната клетка, те образуват gap junction. Конексините се обозначават спрямо молекулното си тегло, напр. конексин 26 е протеин с молекулна маса $26 \mathrm{kDa}$.

Във вътрешното ухо се експресират различни конексини. Сх26 е най-често срещаният (4). Вторият по честота конексин е Сх30. И двата конексина се срещат в поддържащите клетки, базалните клетки на стрия васкуларис, фиброцитите на спиралния лигамент и спиралния лимбус, така също и във вестибуларната част (5).

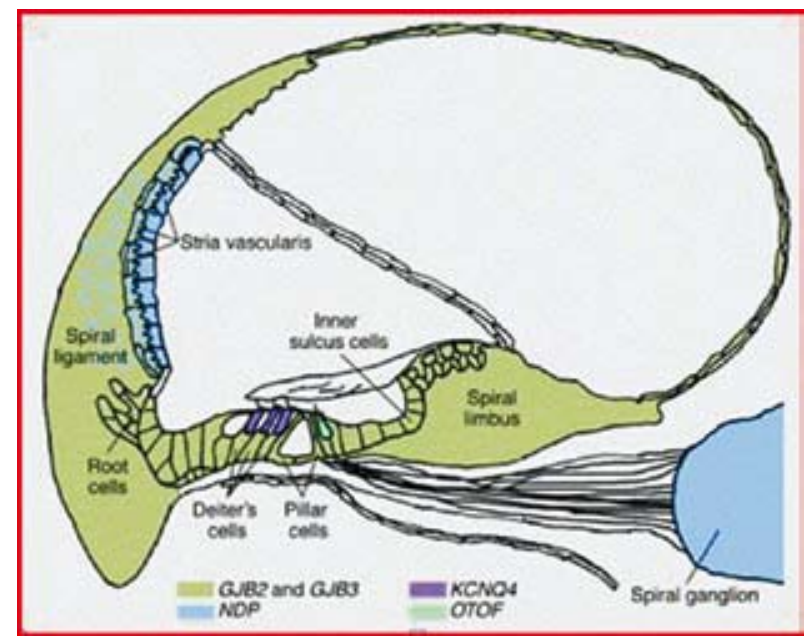

Фиг. 3. Експресия на Сх26 и Сх30 в кохлеята

Пьрвото открито заболяване, дължащо се на увреда на конексините, е заболяването на Charcot-Marie-Tooth-наследствена форма на сензорна и моторна невропатия (3). При него е увреден Сх32. Част от пациентите са със слухова загуба. Някои кожни заболявания са свързани с увреда в Сx26, Сx30, Сх30.3, Сх31. Наследствената катаракта също е резултат на промени в Сх46 и Сх50. Сх43 е свързан със сърдечни заболявания. Глухотата е най-значима от всички конексинсвързани заболявания в човешката популация. Въпреки че наследствената глухота е изключително хетерогенна, мутациите само в един ген $G J B 2$, кодиращ Cx26, допринасят за половината от случаите с NSHL при хората. Две от мутациите са открити от Zelante et al през 1997 г. (6) $35 \mathrm{delG}$ е най-честа в Кавказката популация с преобладаване в Средиземноморския регион (6), a 167delT се среща при ашкеназни евреи (7, 8). Мутацията $35 \mathrm{delG}$ представлява делеция на един гуанин от поредица от 6 гуанина близо до 
амино края на генния продукт и води до изместване рамката на четене и до терминация на транслацията до 13-та аминокиселина. Честотата на носителство на тази мутация като цяло в Европа е 1 на 51 (13). През 1999 г. е открита нова мутация $235 \mathrm{delC}$, по-често срещаща се в азиатската популация, най-вече при японци и китайци (9). Мутациите в GJB2 предизвикват в повечето случаи рецесивна NSHL. Локусът DFNB1 е локализиран на 13q11 (11). T.е. всеки засегнат индивид трябва да наследи по едно копие от нефункциониращия ген от двамата родители. Тези, които носят само един увреден алел, нямат слухова загуба, но има $50 \%$ вероятност да я предадат на своите деца. Между 10-42\% от глухите пациенти са хетерозиготни за GJB2. Това навежда на мисълта за друга близка мутация. По-късно са открити две големи делеции $\operatorname{del(GJB6-D13S1830)~и~del(GJB6-D13S1854).~Те~}$ често се срещат при хетерозиготни пациенти за GJB2. Тези делеции са с по-висока честота при испанци и англичани. Генът GJB6 кодира Cx30.

Сх31 се експресира във фиброцити втори тип на спиралния лимбус и спиралния лигамент, а също така и в слуховия нерв. Установена е функционална взаимовръзка между гените, кодиращи Сх26 и 31. Има факти, доказващи, че мутациите на GJB2 и GJB3 могат взаимно да доведат до слухова загуба при хетерозиготно състояние на двата гена. Този конексин е отговорен и за кожното заболяване еритрокератодермия вариабилис.

Друг конексин Сх32, кодиран в GJB1, е свързан c X-хромозомата и е най-вероятната причина за периферната невропатия при слуховите увреждания. Наличието на невропатия е от особено важно значение при прогнозиране на резултатите от оперативното лечение на глухотата.

$\mathrm{У}$ нас честотата на слуховите увреждания се движи в международно приетите граници. Така в България ежегодно се раждат около 65 глухи деца при раждаемост около $60000-65000$ годишно (близо $8 \%$ от децата са с рискови фактори за увреда на слуха). Националният центьр по здравна информация не разполага с данни относно честотата на слуховите увреждания в България и разпределението им по нозологични единици (12). Не е известен и броят на рехабилитираните деца, както и на децата със слухови увреждания, които посещават училищата, обучаващи деца без подобни увреждания.

До 2009 год. в България са правени само спорадични изследвания на наследствената слухова загуба. През 2009-2010 год. в Катедрата по УНГ болести на МУ - София, съвместно с Центьра по молекулна медицина, беше направено генетично изследване на 59 пациенти със слухова увреда с неизяснена етиология. Пациентите са подбрани по предварително определени критерии. Снета е подробна анамнеза, извършен е общ и УНГ статус. Функцията на слуховия анализатор е оценена посредством ТПА, тимпанометрия, акустикус рефлекс, OAE, ASSR, CCEП. Извършено е генетично изследване за мутации в GJB2. В 34\% от пациентите се установи $35 \mathrm{delG}$ в хозиготно, а в $15 \%$ в хетерозиготно състояние. Открита е и нова, непубликувана до момента мутация Ile121Asn при един от пациентите. C това проучване се постави началото на ДНК банка от пациенти с увреден слух в Центьра по молекулна медицина към МУ - София.

Повечето форми на наследствена слухова загуба са моногенни, въпреки че са открити и дигенни взаимодействия, включващи специфични локуси. Ето защо нашата следваща цел беше да изследваме и други гени, отговорни за слухова загуба. През 2012 год. стартирахме нов проект за генетично изследване на пациенти с NSHL. Събраните пациенти се изследват за мутации в двата гена GJB2 и GJB6.

Установявайки молекулнте механизми на слуховата загуба, се изясняват клиничната картина, ходът на заболяването и очакваните резултати след евентуална кохлеарна имплантация. Генетичната консултация дава информация на семейството за рискове при следваща бременност. Навременното диагностициране и лечение на слуховата загуба е от първостепенно значение за социализирането на децата с увреден слух.

\section{Литература:}

1. Lodish, Harvey F.; Arnold Berk, Paul Matsudaira, Chris A. Kaiser, Monty Krieger, Mathew P. Scott, S. Lawrence Zipursky, James Darnell (2004).Molecular Cell Biology (5th ed.). New York: W.H. Freeman and Company. pp. 230-1.ISBN 0-7167-4366 3

2. Petit C., Levilliers J, Hardelin JP. Molecular genetics of hearing loss. Annu Rev Genet 2001; 35:589-646 
3. Bergoffen J, Scherer SS, Wang S, Scott, MO, Bone LJ, Paul DL, Chen K, Lensch MW, Chance PF, Fischbeck KH, Connexin mutations in X-linked Charcot-Marie-Tooth disease. Science1993; 262: 2039-2042.

4. Forge A, Becker D, Casalotti S, Edwards J, Evans WH, Lench N, Souter M. Gap junctions and connexin expression in the inner ear. Novartis Found Symp 1999; 219: 134-150.

5. Lautermann J, ten Cate WJ, Altenhoff P, Grummer R, Traub O, Frank H, Jahnke K, Winterhager E. Expression of the gap-junction connexins 26 and 30 in the rat cochlea. Cell Tissue Res 1998; 294: 415-420.

6. Zelante L, Gasparini P, Estivill X, Melchionda S, D’Agruma L, Govea N, Mila M, Monica MD, Lutfi J, Shohat M, Mansfield E, Delgrosso K, Rappaport E, Surrey S, Fortina P. Connexin26 mutations associated with the most common form of non-syndromic neurosensory autosomal recessive deafness (DFNB1) in Mediterraneans. Hum Mol Genet 1997; 6: 1605-1609.

7. Kelley PM, Harris DJ, Comer BC, Askew JW, Fowler T, Smith SD, Kimberling WJ. Novel mutations in the connexin 26 gene (GJB2) that cause autosomal recessive (DFNB1) hearing loss. Am J Hum Genet 1998; 62: 792-799.

8. Morell RJ, Kim HJ, Hood LJ, Goforth L, Friderici K, Fisher R, Van Camp G, Berlin CI, Oddoux C, Ostrer H, Keats B, Friedman TB. Mutations in the connexin 26 gene (GJB2) among Ashkenazi Jews with nonsyndromic recessive deafness. N Engl J Med 1998; 339: $1500-1505$.

9. Fuse Y, Doi K, Hasegawa T, Sugii A, Hibino H, Kubo T. Three novel connexin26 gene mutations in autosomal recessive non-syndromic deafness. NeuroReport 1999; 10: 1853-1857.

10. Lerer I, Sagi M, Ben-Neriah Z, Wang T, Levi H, Abeliovich D. A deletion mutation in GJB6 cooperating with a GJB2 mutation in trans in nonsyndromic deafness: a novel founder mutation in Ashkenazi Jews. Hum Mutat 2001; 18: 460.

11. Guilford P, Ben Arab S, Blanchard S, Levilliers J, Weissenbach J, Belkahia A, Petit C. A non-syndrome form of neurosensory, recessive deafness maps to the pericentromeric region of chromosome 13q. Nat Genet 1994; 6: 24-28.

12. Национална програма за слухов скриниг 2006-2010год.

13. Maria Bitner-Glindzicz, Hereditary deafness and phenotyping in humans, British Medical Bulletin 2002;63: 73-94 